
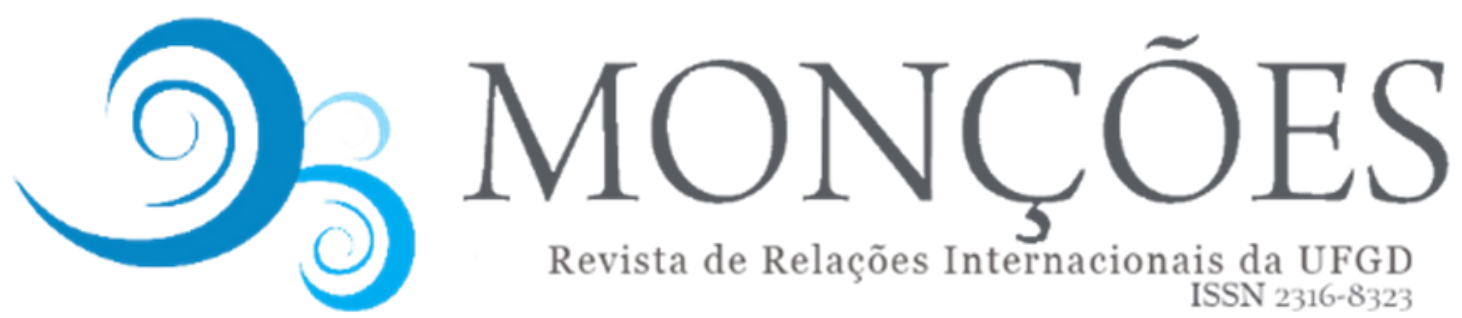

Revista de Relações Internacionais da UFGD

ISSN 2316-8323

\title{
ARIGÓS EM PORTO VELHO: A CONSTRUÇÃO DA ORDEM E DA ESTRATIFICAÇÃO SOCIAL A PARTIR DA VIOLÊNCIA INSTITUCIONALIZADA PELO ESTADO
}

\author{
MARCO ANTÔNIO DOMINGUES TEIXEIRA \\ Professor Associado do Departamento de História da Universidade \\ Federal de Rondônia (UNIR), Porto Velho (RO), Brasil \\ ORCID: https://orcid.org/0000-0001-6725-023X
}

marcoteixeira204@gmail.com

\begin{abstract}
RESUMO: A migração nordestina é um fenômeno permanente na história do Brasil, desde a segunda metade do século XIX. O Nordeste, como região pobre e famélica, surge de um imaginário propositalmente construído ao longo do Império e durante a República. A seca foi considerada uma verdadeira indústria humana para prover aos centros produtores, mão de obra barata e disponível a qualquer tipo de serviço. Na década de 1940, o Estado Varguista apropriou-se dessa mão de obra, criando a figura do soldado da borracha, um trabalhador com educação profissional militarizada e prontamente subordinado às autoridades que governariam sua vida nos seringais. Mesmo diante desse projeto fascista, os arigós souberam construir alternativas e tornaram-se o elemento chave para o povoamento da Amazônia naquele período. Asseguraram, com seu trabalho e suas vidas, a produção de borracha para os esforços da Segunda Grande Guerra. Em seus deslocamentos, eram confinados aos pontos de concentração, locais disciplinarizados e autoritários, moldados a partir da mentalidade fascista e higienista da época. Em Porto Velho, o campo de pousio chamou-se Arigolândia e deu origem a um bairro periférico, majoritariamente habitado por nordestinos. Este trabalho pretende insvestigar a formação do bairro Arigolândia no contexto urbano e social da cidade de Porto Velho. O método de pesquisa utilizado foi baseado em revisão bibliográfica e documental, bem como, em entrevistas organizadas a partir dos métodos da História do Tempo Presente e das técnicas da História Oral.
\end{abstract}

PALAVRAS-CHAVE: Arigós, Campos de Pousio, Porto Velho, Periferias Sociais, Estado Autoritário.

\section{ARIGÓS IN PORTO VELHO: THE CONSTRUCTION OF ORDER AND SOCIAL STRATIFICATION FROM INSTITUTIONALIZED STATE VIOLENCE}

\begin{abstract}
Northeastern migration is a permanent phenomenon in Brazilian history since the second half of the 19th century. The Northeast as a poor and famished region, arises from an imaginary purposefully built throughout the Empire and during the Republic. The drought was considered a true human industry to provide to the producing centers, cheap labor and available to any type of service. In 1940, the Varguista State appropriated this labor, creating the figure of the rubber soldier, a worker with a professional education militarized and promptly subordinated to the authorities that would govern his life in the rubber plantations. Even in the face of this fascist project, the landowners knew how to construct alternatives and became the key element of settlement in the Amazon. They secured with their work and their lives the production of rubber for the efforts of the Second World War. In their displacements they were confined to the points of concentration, disciplinary and authoritarian places, molded from the fascist and hygienist mentality of the time. In Porto Velho, the fallow field was called
\end{abstract}

Monções: Revista de Relações Internacionais da UFGD, Dourados, v.9, n.18, jul./dez.

Disponível em: http://ojs.ufgd.edu.br/index.php/moncoes

DOI 10.30612/rmufgd.v10i18.11180 
Arigolândia and gave rise to a peripheral neighborhood, mostly inhabited by Northeasterners. This work intends to inscribe the formation of the neighborhood Arigolandia in the urban and social context of the city of Porto Velho. The research method used was based on bibliographical and documentary revision, as well as on interviews organized from the methods of the Present Time History and Oral History techniques.

KEY WORDS: Arigós, Fields of rest, Porto Velho, Social Peripheries, Authoritarian State.

\section{ARIGÓS EN PORTO VELHO: LA CONSTRUCCIÓN DEL ORDEN Y LA ESTRATIFICACIÓN SOCIAL DESDE LA VIOLENCIA INSTITUCIONALIZADA POR EL ESTADO}

RESUMEN: La migración nororiental ha sido un fenómeno permanente en la historia de Brasil desde la segunda mitad del siglo XIX. EI Noreste, como región pobre y familiar, surge de un imaginario construido a propósito en todo el Imperio y durante la República. La sequía fue considerada una verdadera industria humana para dotar a los centros de producción de mano de obra barata y disponible para cualquier tipo de servicio. En la década de 1940, el Estado Varguista se apropió de esta mano de obra, creando la figura del cauchero, un trabajador con formación profesional militarizada y puntualmente subordinado a las autoridades que regirían su vida en los caucheros. Incluso ante este proyecto fascista, los arigós supo construir alternativas y se convirtieron en el elemento clave para la población de la Amazonía en ese momento. Con su trabajo y sus vidas, aseguraron la producción de caucho para los esfuerzos de la Segunda Guerra Mundial. En sus desplazamientos, fueron confinados a puntos de concentración, lugares disciplinados y autoritarios, moldeados desde la mentalidad fascista e higienista de la época. En Porto Velho, el campo en barbecho se llamó Arigolândia y dio lugar a un barrio periférico, habitado en su mayoría por nororientales. Este trabajo pretende investigar la formación del barrio de Arigolândia en el contexto urbano y social de la ciudad de Porto Velho. El método de investigación utilizado se basó en la revisión bibliográfica y documental, así como en entrevistas organizadas a partir de los métodos de la Historia de la Actualidad y las técnicas de la Historia Oral.

PALABRAS CLAVE: Arigós, Campos de Barbecho, Porto Velho, Periferias sociales, Estado autoritario.

\section{Introdução}

Povoada por migrantes nordestinos, a "Arigolândia" constituiu-se a partir de um campo de confinamento de jovens nordestinos destinados aos seringais da região. $O$ bairro formou-se na década de 1940, nos limites da área urbana do município de Porto Velho, a partir da existência de dois grandes barracões sem paredes e cobertos de palha, que eram destinados ao "abrigo dos nordestinos que chegavam à cidade (BORZACOV, 2012). Segundo Machado de Lima (2017), os nordestinos que chegavam a Porto Velho, desembarcavam no porto do Cai N'Água e dali eram levados sob escolta da guarda policial local, sob a mira de armas, para um campo de descanso, classificado pelo narrador como campo de concentração. O espaço delimitado para sua permanência, até que fossem enviados para algum seringal, era cercado por arame farpado e mantido sob vigilância armada. As saídas para além 


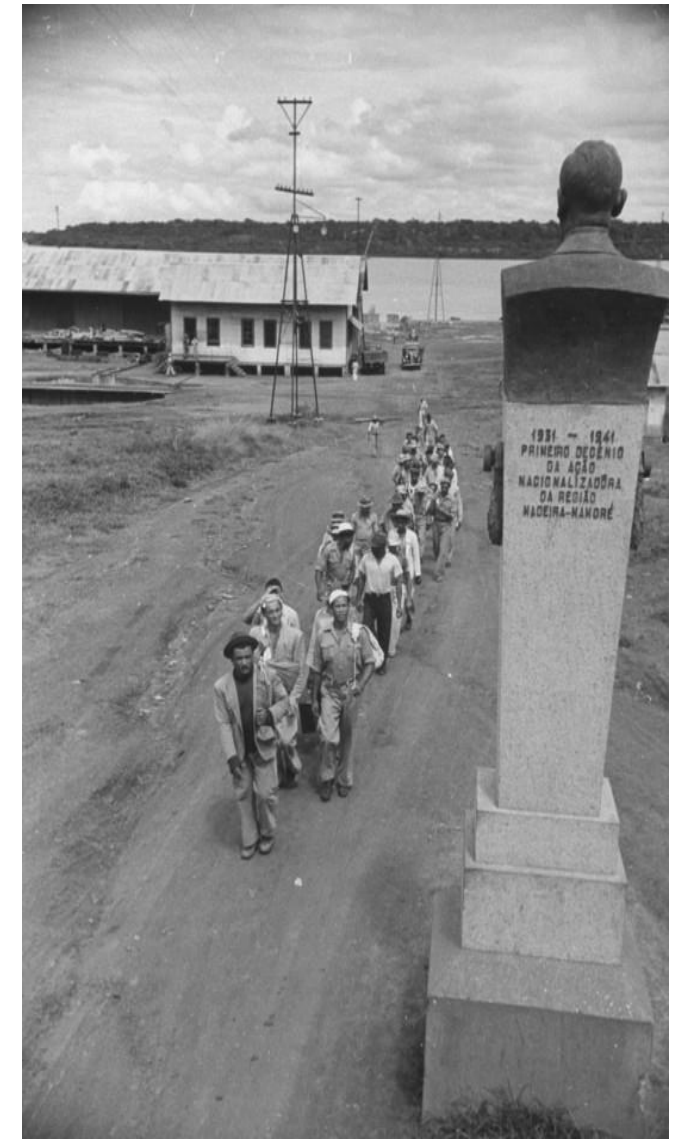

Figura 1 - O Desembarque dos Arigós em Porto Velho (1944)

Em fila e sob o olhar pétreo do busto do presidente Getúlio Vargas, os migrantes nordestinos "marcham" para o campo de repouso denominado Arigolândia, onde deveriam aguardar a seleção dos seringalistas que os enviariam para o trabalho nas florestas dos vales do Madeira. Fonte: Arquivos do Saudosismo Portovelhense. Disponível em: <https://pt-br.facebook.com/groups/199910546786793/>.

Dentro deste "acampamento" provisório, prevaleciam leis rígidas e forte disciplina, de caráter militarizado, estando os seus integrantes sujeitos a trabalhos, exercícios físicos, treinamentos e realização de diversas outras tarefas. O campo de repouso, ou de espera foi chamado Arigolândia, uma vez que seus ocupantes nordestinos eram conhecidos pelo nome pejorativo de arigós:

Adjetivo depreciativo utilizado pelos moradores da Amazônia para qualificar os nordestinos que vinham trabalhar nos seringais. Arigós são aves de arribação ou migratórias, que quando descem, em bando sobre um campo lavrado, destroem a plantação. Considerava-se que os jovens nordestinos, embarcados nos portos litorâneos da Bahia até o Maranhão, eram desordeiro e causavam grande tumulto ao desembarcarem nas cidades ribeirinhas amazônicas. Segundo o Dicionário Informal, Arigó pode ser entendido como: 
Que ou aquele que trabalha em construção de estradas, engenhos e usinas de açúcar; cassaco. Em alguns lugares do Nordeste, segundo depoimento de um nordestino, arigó tem esta acepção por significar ave de arribação, migrante. Quanto ao trabalhador migrante, diz-se que é "arigó" quando vai e "paroara" quando volta. Seus sinônimos são: simplório, tolo, sertanejo, jeca, grosseiro, mal educado, caboclo, caburé, canguçu. (DICIONÁRIO INFORMAL; Arigó).

Alguns desses trabalhadores terminavam não sendo encaminhados para os seringais, quer por total inaptidão, por indisciplina ou por algum tipo de favorecimento das autoridades locais que controlavam o campo. Aqueles que permaneciam, se instalavam em barracos de madeira cobertos de palha, cultivando pequenos roçados de mandioca (Manihot sculenta) ou verduras diversas, além da criação de cabras (Capra aegagrus hircus), porcos (Sus scrofa domesticus) e galinhas (Gallus gallus domesticus). Alguns se dedicavam a atividades comerciais de pequena monta e, quase todos foram utilizados como mão de obra na construção dos primeiros bairros residenciais de operários da Estrada de Ferro Madeira-Mamoré (doravante EFMM).

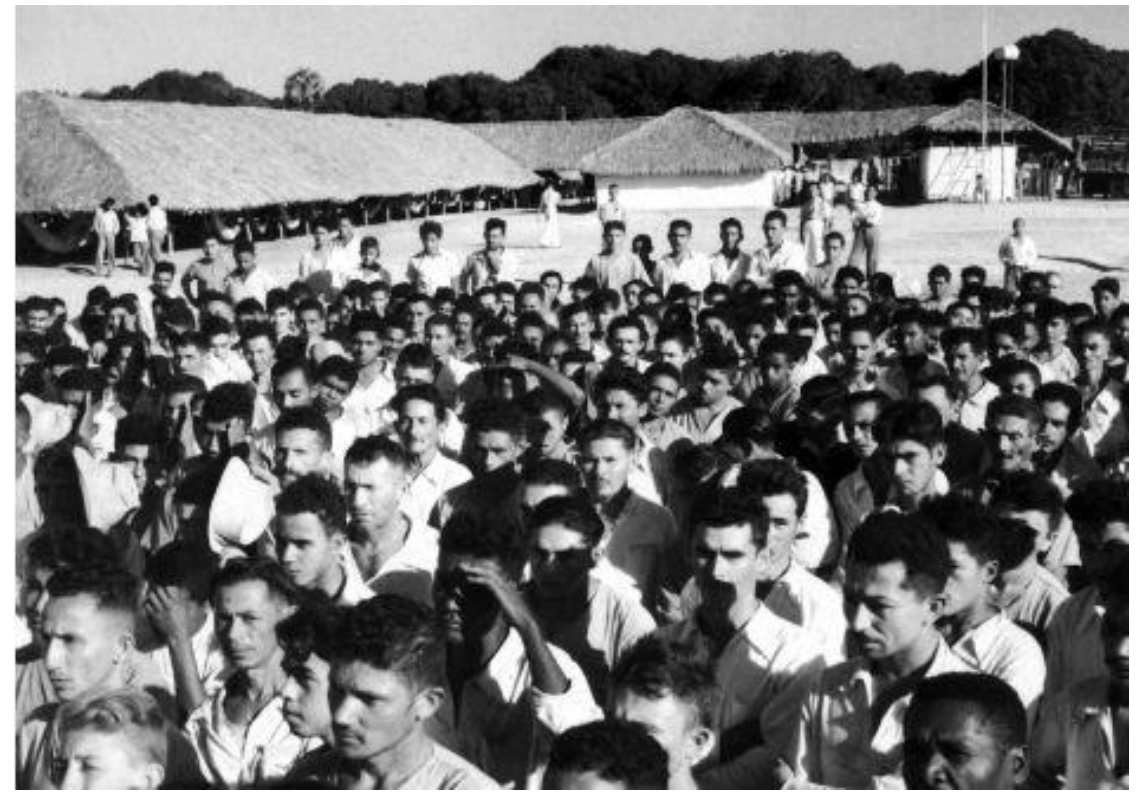

Figura 2 - Alojamento de Arigós na Amazônia.

Para acelerar a transferência de trabalhadores nordestinos para a Amazônia e aumentar significativamente a produção de borracha, os governos americano e brasileiro encarregaram diversos órgãos do gerenciar os programas de deslocamento dos trabalhadores nordestinos para os seringais amazônicos. Fonte: Arquivo Serviço Especial de Mobilização de Trabalhadores para a Amazônia (SEMTA).

A história dessa população da área urbana e de onde se instalaram, ainda é pouco conhecida dos pesquisadores locais, embora esteja viva na memória dos mais 
antigos moradores e, ainda possa ser resgatada em alguns poucos documentos e em muitas memórias de narradores idosos que ainda vivem na Arigolândia.

Em Microfísica do Poder (FOUCAULT, 2005) nos apresenta uma reflexão de que as delimitações espaciais são estratégias que se camuflam, sob a forma de discursos e estão eminentemente ligadas às relações de poder. Segundo Albuquerque Júnior (1999):

Antes de se reportar à geografia, a noção de região se refere a uma noção fiscal, administrativa, militar (vem de regere, comandar). Ela não diz respeito apenas a uma divisão natural do espaço, nem a um recorte do espaço econômico. Tal como ocorre com a "nação", a "região" se liga diretamente às relações de poder e sua espacialização (ALBUQUERQUE JÚNIOR, 1999)

O Nordeste, tal qual o conhecemos atualmente, caracterizado como uma região de extrema pobreza e clima hostil, foi fundado ao final do século XIX e, nas primeiras décadas do século XX. Ao longo da maior parte da História Colonial e Imperial do Brasil, entre os séculos XVI ao XIX, a região foi tida como importante polo de riqueza e prosperidade. Continuando sua análise, Albuquerque Júnior considera a premente necessidade de resgatar para a história e para a política o que é considerado como natural.

Torna-se imperativo entendermos o conceito de região, para podermos compreender, também, a ideia de Nordeste, pobreza e de seus habitantes em situação de migração, comumente chamados "arigós" na primeira metade do século XX. Para Vieira:

O conceito de região tem sido utilizado por todos os campos do conhecimento, mas as discussões mais acirradas em torno de uma sistematização desse conceito têm ficado por conta da Geografia, uma vez que a região constitui uma categoria analítica dessa ciência. (VIEIRA, 2013, p. 23)

A estrutura regional nacional, tal qual a conhecemos é recente, no auge das migrações nordestinas para a Amazônia, na segunda metade do século XIX, a região era conhecida como Grande Norte Oriental, entre 1913 (data da primeira divisão territorial oficial do país), os estados do Maranhão, Piauí, Ceará, Rio Grande do Norte, Paraíba, Pernambuco, Alagoas, eram chamados de estados da Região Norte Oriental, enquanto Bahia e Sergipe, integravam, juntamente, com Minas Gerais, Rio de Janeiro e Espírito Santo, a Região Ocidental. Esse é o período da intensa migração dos Soldados da Borracha. 
Entre 1940 e 1945, o Maranhão e o Piauí integravam a Região Norte e Bahia, Sergipe e Espírito Santo formavam a região Leste. O Nordeste era composto por Ceará, Rio Grande do Norte, Pernambuco, Paraíba e Alagoas. Em 1945, novamente mudaram-se os limites das diversas regiões brasileiras. O Nordeste ganha uma configuração mais próxima da atual, abrangendo os estados do Maranhão, Piauí, Ceará, Rio Grande do Norte, Paraíba, Pernambuco e Alagoas. A Bahia e Sergipe permaneceram como Região Leste Setentrional. Finalmente, esses dois estados, foram incorporadas ao Nordeste em 1970. Já a Amazônia teve o acréscimo dos territórios do Guaporé, Amapá e Rio Branco em 1945 e, por fim, ainda o Tocantins em 1990.

Conforme ressaltou Albuquerque Jr (1999), o conceito de região tem uso mais amplo na geografia e nos estudos militares (regere). Nas ciências geográficas, conforme nos ensina Gomes (2003), o termo "região" abrange três áreas de domínio: o domínio do conhecimento do senso comum, o domínio da administração e o domínio do conhecimento científico. De acordo com Corrêa, seguidor da corrente epistemológica da Nova Geografia, a conceituação do termo região passou a conceber o termo como sendo "um conjunto de lugares onde as diferenças internas entre esses lugares são menores que as existentes entre eles e qualquer elemento de outro conjunto de lugares" (GOMES, 2003, p. 32). Milton Santos (1996) considera que para se estudar a região é preciso levar em conta a dialética existente entre o regional e o global e não cometer o equívoco de conceber a região como uma unidade autônoma que se explica por si mesma.

Tomando todas essas premissas como fundamentais em nossas considerações, vemos que a construção do conceito de Nordeste, como uma região desolada pela pobreza, pela hostilidade climática, por secas intermináveis, pela fome e pela extrema violência nem sempre correspondeu à exatidão da percepção dos próprios residentes, que se viam de diversas maneiras. O termo é uma construção híbrida do poder republicano, notadamente do período 1940/60, e foi apropriado pelo Estado Varguista para caracterizar um conjunto de estados cujos maiores investimentos, do poder republicano, situaram-se no campo da transposição de enormes contingentes populacionais para outras localidades do país, tanto pela via da propaganda, nem sempre honesta, quanto pela via da coerção, através de alistamentos e aliciamentos de agentes públicos. Nessas novas terras, o dinamismo 


\section{MARCO A. D. TEIXEIRA}

da economia requeria maior número de trabalhadores, dispostos a qualquer tipo de atividade para sobreviver. O nordestino passou e ser, então, sinônimo de mão de obra acessível, barata e descartável.

Seguindo esse mesmo pensamento, é necessário entender a condição dos retirantes das diversas secas que flagelaram a região entre os anos de 1850 e 1950, período em que se intensificaram as migrações nordestinas para a Amazônia. A identificação do Nordeste como uma região de pobreza e aridez, nem sempre fez sentido na História do Brasil. Ao estudarmos o período colonial, a região é apresentada como próspera produtora de commodities, capaz de abastecer os mais exigentes mercados europeus. Entretanto, o Nordeste é pensado, a partir de meados do século XIX, como um celeiro de exportação de trabalhadores nos mais diversos sentidos. Com a crise do açúcar, os escravizados nordestinos foram, paulatinamente, transferidos para o Vale do Paraíba, entre São Paulo, Rio de Janeiro e Minas Gerais. Ante a falta de oportunidades econômicas, moradores das zonas mais áridas e mesmo do agreste, desassistidos pelos poderes públicos, tinham como única estratégia a migração, causando grande caos aos centros litorâneos e sendo vistos como uma ameaça à ordem e estabilidade.

A condição de migrantes parece, à primeira vista, inerente ao próprio nordestino, sempre em deambulação, fugindo dos rigores ambientais e transformando-se em mão-de-obra disponível em todas as ocasiões. De fato, as províncias do Norte Oriental, da Bahia e do Sergipe, passaram à condição, permanente, de exportadores de trabalhadores de baixo custo e manutenção, desde a crise do açúcar iniciada em 1828.

Em meados do século XIX, a situação de empobrecimento se agravara, na mesma medida em que as províncias do Rio de Janeiro, Minas Gerais e São Paulo prosperavam com o advento do café, importando a escravaria ociosa e contribuindo para o empobrecimento geral das províncias do Grande Norte. As secas sempre foram as maiores responsáveis pelos deslocamentos humanos na região do atual Nordeste, porém, um olhar mais acurado, nos apontará diversos outros problemas que contribuíram para que os camponeses locais migrassem, abandonando o campo e buscando, primeiramente, as cidades regionais. Sem outras opções, terminavam por migrar para qualquer região possível onde houvesse possibilidades de reiniciar a vida e alcançar alguma dignidade. 
Estrategicamente, foi com Dom Pedro II e, posteriormente, com os governos republicanos, que essa situação ambiental passou a ter um lado útil ao sistema político, que sempre necessitando abastecer ocasionais mercados de trabalho, voltados para produção de exportação, a baixíssimo custo, em outras regiões. Há mais de um século e meio, o Estado Brasileiro vem recorrendo ao argumento da seca do sertão nordestino e à propaganda que promove a ideia de novos eldorados, para estimular a migração de milhões de nordestinos para outras regiões. Por outro lado, essa mesma seca, favorece os potentados locais e regionais, quer com os investimentos e auxílios que parlamentares e o governo federal aplicam na região, quer como forma de controle ideológico e político das camadas mais pobres, sempre sujeitadas ao mando senhorial.

Assim, essa população vem suprindo demandas dos mercados por mão de obra de baixo custo, enquanto o Estado atuou ampliando seus horizontes de povoamento de fronteiras, como no caso da Amazônia, ou de mercados, onde os habitantes locais, mais qualificados e menos empobrecidos, representavam um custo maior, como foi o caso de São Paulo.

Neste trabalho abordaremos a questão da migração direcionada e controlada pelo Estado Brasileiro e pelo capital norte americano, para a Amazônia, especificamente para a cidade de Porto Velho que, nos anos 1940, recebeu milhares de nordestinos, os quais, em sua maioria, deveriam ser dispersados pelas áreas florestais dos seringais do Madeira, Mamoré, Jamari, Machado, Candeias e Guaporé. A maior parte desses migrantes, deslocados de forma autoritária e organizada, atuou como soldados da borracha no período 1943 a 1945. Quando os interesses da guerra cessaram, o estímulo e o controle migracional cessaram também. Os seringais logo começaram, mais uma vez, o processo de despovoamento e as poucas cidades existentes, no então Território do Guaporé, cresceram com uma nova onda de migração, dessa vez interna e de caráter rural para urbano.

Ao longo desse período de migrações controladas pela Comissão Administrativa de Encaminhamento de Trabalhadores para a Amazônia (CAETA), Serviço Especial de Mobilização de Trabalhadores para a Amazônia (SEMTA) e outros órgãos, as cidades que recebiam os nordestinos/arigós para distribuí-los em seringais, construíam "alojamentos" denominados campos de pouso, ou de pousio, 
para confinar os jovens migrantes e evitar, dessa forma, distúrbios e transgressões à ordem social reinante.

Em Porto Velho, o campo de Pouso ou de Pousio, como era conhecido, se chamou Arigolândia e foi composto por dois enormes barracões de madeira, com grandes áreas em aberto e cobertos de palha. Para além dos barracões havia um enorme espaço livre para circulação, exercícios calestênicos e treinamentos para o trabalho nos seringais. A área era guardada e a permanência em seu interior era exigida até que cada um dos arigós fosse escolhido por algum seringalista para trabalhar em suas terras. Seu diretor foi o professor Enos Eduardo Lins (BORZACOV, 2019).

Mais tarde, quando o campo de pousio foi desativado, existiam ao seu lado alojamentos para as guardas que garantiam a segurança do campo, moradias ao entorno, pequenos comércios capazes de abastecer o que ali, ficavam "confinados". O espaço foi, então, reaproveitado e, construiu-se o Quartel da Guarda Territorial do Guaporé. Ao seu arredor, casebres de adobe ou madeira cobertos de palha e sem nenhum conforto, anunciavam o nascimento do bairro Arigolândia.

\section{Metodologia da pesquisa}

Este artigo é o resultado de uma longa entrevista com o professor Dr Abnael Machado de Lima, Doutor Honoris Causa pela Universidade Federal de Rondônia, falecido em julho de 2019. Em nossas últimas conversas, abordamos as histórias do bairro Arigolândia, onde sua família ainda reside, hoje na região central da cidade de Porto Velho. Em suas narrativas ele me explicou o nascimento do bairro e como os arigós, que chegavam a Porto Velho, eram ali deixados, até que algum seringalista os escolhesse para trabalhar em suas terras. Assim sendo, a pesquisa tem, primeiramente, um caráter de pesquisa oral e documental. De acordo com Bom Meihy (2005), pesquisador especializado em História Oral, trabalhar pela via da memória possibilita ao sujeito que narra e que é alvo da pesquisa, "uma outra compreensão do período histórico evocado, qual seja: A presença do passado no presente imediato das pessoas é a razão de ser da história oral".

Considerei o assunto muito importante e pedi ao mesmo que redigisse uma memória sobre o tema e, em dois dias recebi 4 folhas digitadas contando a História da Arigolândia e de seu campo de pouso de nordestinos. 
O tema me despertou ainda mais atenção e passei a buscar mais informações sobre o assunto, encontrando dados sutis em diversas obras que falavam sobre os "alojamentos" organizados no litoral para receber os sertanejos e os outros "alojamentos" organizados nas cidades amazônicas que receberiam os, então, "soldados da borracha", um nome pomposo para um trabalhador que viveria em situações muito próximas de modelos escravizantes.

Diante da realidade de muitas evidências, retomei algumas entrevistas com o professor Abnael Machado de Lima e continuei e trabalhar na busca de bibliografias mais específicas sobre o assunto, ao mesmo tempo em iniciei a leitura de material bibliográfico referente ao controle dos corpos e das vidas pelo Estado. A pesquisa bibliográfica se adensou e passei a buscar outras informações em bancos de teses e em bibliotecas regionais e virtuais, principalmente na Amazônia e Nordeste.

Conforme Tumeleo, a pesquisa bibliográfica:

É um procedimento exclusivamente teórico, compreendida como a junção, ou reunião, do que se tem falado sobre determinado tema. Ela é feita a partir do levantamento de referências teóricas já analisadas, e publicadas por meios escritos e eletrônicos, como livros, artigos científicos, páginas de web sites. Por isso, qualquer trabalho científico deve ser iniciado com uma pesquisa bibliográfica. (TUMELEO, 2019).

A pesquisa bibliográfica aplica-se ao estudo e análise de diferentes posicionamentos e ideologias acerca de um tema. Para Fonseca:

\footnotetext{
Entretanto, existem pesquisas científicas que se baseiam unicamente na pesquisa bibliográfica, procurando referências teóricas publicadas com 0 objetivo de recolher informações ou conhecimentos prévios sobre o problema a respeito do qual se procura a resposta (FONSECA, 2002, p. 32):
}

Ao lado das pesquisas bibliográficas e de entrevistas orais, dediquei-me à busca de imagens e documentos da época e encontrei algumas poucas fotografias, mas consegui ter acesso a uma ou outra página escrita que sobreviveu às décadas. A pesquisa iconográfica oferece uma:

[...] contribuição científica e estética que os registros fotográficos trazem em seus conteúdos para a fixação da memória é ainda pouco valorizada. Estudiosos de história, comunicação e diferentes campos das ciências humanas tem, em número crescente, se interessado pela imagem, em especial a fotográfica, como fonte e instrumento de pesquisas e reflexão. (LABORATÓRIO DE ESTUDOS SOBRE ETNICIDADE, RACISMO E DISCRIMINAÇÃO (USP) - Iconografia)

A pesquisa oral foi o foco deste trabalho e me auxiliou a entender questões que considero atuais e que, de certa forma, ainda, podem ser buscadas nas memórias 
dos poucos indivíduos vivos daquele tempo e em correspondências e anotações que deixaram entre seus escritos.

Por fim, buscamos entender o fenômeno desses campos, tão comuns no Brasil, desde 1915 até 1976, pela via da pesquisa documental:

A pesquisa documental é um tipo de pesquisa que utiliza fontes primárias, isto é, dados e informações que ainda não foram tratados científica ou analiticamente. A pesquisa documental tem objetivos específicos e pode ser um rico complemento à pesquisa bibliográfica.

Os documentos analisados podem ser atuais ou antigos, e podem ser usados para contextualização histórica, cultural, social e econômica de um lugar ou grupo de pessoas, em determinado momento da história. Por essa razão, é um tipo de pesquisa bastante utilizado nas ciências sociais e humanas. (SIGNIFICADOS. Pesquisa Documental).

Assim, ao optarmos por um estudo de conflitos de interesses entre os grupos formadores e colonizadores da região, na metade do século $X X$, escolhemos uma questão atual, já discutida em outras regiões, mas ainda não trabalhada pelos historiadores e cientistas sociais locais. A colonização nordestina da região, nos primeiros anos da década de 1940, é, certamente, um tema abordado por todos os pesquisadores da história local. No entanto, o modelo autoritário que estruturou essa migração, ainda deixa lacunas que não foram abordadas. Para tentar incitar um ovo debate local sobre a presença dos nordestinos na cidade de Porto Velho, na primeira metade dos anos 1940, trabalharemos com a História do Tempo Presente, numa tentativa de reflexão sobre as relações político-sociais desses migrantes deslocados para a Amazônia, destacando e entendendo os conflitos, alianças e a construção das relações de poder e subalternidade entre os agentes dessas empreitadas colonizadoras.

Para nos situarmos no universo teórico da História do Tempo Presente utilizamos autores como Ferreira (2000), Dosse (2011), Delgado e Ferreira (2013), Fico (2013) e Neto e Ramos (2014). A busca pelas fontes acerca da História Regional de Rondônia, é mais fluída, uma vez que grande parte dos arquivos referentes aos séculos $X I X$ e $X X$ se perdeu. Entretanto, é possível acessar um vasto e bem conservado arquivo sobre o seringalismo na bacia do Madeira, no Palacio de Las Artes em Guayara-Merin, na fronteira rondoniense Brasil/Bolívia e nos arquivos de Riberalta, e Trinidad. Diante da escassês de fontes documentais da maior parte do século $X X$, podemos recorrer a algumas poucas obras que registram memórias de trabalhadores que viveram na região em épocas próximas ao período estudado. Dentre esses autores podemos destacar: Neville Craig (1947), Benigno Bouzas 
(1950), Vitor Hugo (1959), Yedda Pinheiro Borzacov (2019), Amizael Gomes da Silva (2001), Marco Antônio Domingues Teixeira (2008), Marco Antônio Domingues Teixeira e Dante Ribeiro da Fonseca (1998). Como forma complementar de dados recentes utilizamos os recursos da História Oral a partir dos trabalhos de Paul Thompson (1992), José Carlos Sebe Bommehey e Fabíola Holanda (2018). O foco dos estudos em direção ao confinamento dos trabalhadores pode ser encontrado na dissertação de mestrado de Frederico Alexandre de Oliveira LIMA (2013) e no livro de Kênia Sousa Rios (2014).

\section{O Estado autoritário e o trabalhador não qualificado na Amazônia}

A sociedade nacional, nas primeiras décadas do século XX, era composta por milhares de libertos da escravidão e por milhões de trabalhadores livres, sem nenhum tipo de qualificação profissional, a não ser o trabalho em roças e plantações. Tal situação produziu um enorme contingente de desempregados e, também, provocou uma migração de grande porte entre as regiões onde o trabalho tradicional perdia força por quaisquer motivos e outras, que requeriam maior quantidade de mão de obra disponível, viesse de onde fosse.

Nesse contexto, os estados do Norte, Nordeste e Leste (ver mapa abaixo) atingidos pela seca e pelo declínio de suas produções monocultoras tradicionais ofereciam um formidável "celeiro humano" de trabalhadores que se dispunham a qualquer tipo de serviço e a custos muito baixos. Foram, aproximadamente $65.000 \mathrm{a}$ 70.000 pessoas, destinadas para os estados e territórios da Amazônia, então, novamente, voltados à produção da borracha. Conforme ressalta Lima:

Esses sujeitos são homens e mulheres, indivíduos em cujo cotidiano, por
meio de suas experiências próprias, construíram um caminho para a
sobrevivência no interior de um mundo duro, violento e árido como o chão de
onde partiram. Nessa jornada, que é também de desenraizamento, de perdas
e abandonos, recusam, afirmam, ressignificam identidades e papeis sociais,
moldando-se conforme seus interesses e os imperativos das tensões,
contradições, conflitos e resistências a que se veem envolvidos. Contudo, não
são sujeitos abstratos e homogêneos, despersonalizados e com vontades
determinadas, como queria a historiografia tradicional (LIMA, 2013, p. 15)

A migração desses milhares de cidadãos, tidos como desocupados e potenciais ameaças à ordem local era reforçada pelo conservadorismo dos mandantes locais, regionais e nacionais. Em 1941, já em Plena ditadura do Estado Novo, Getúlio Vargas decretou a Lei da Vadiagem, que se tornou o segundo crime mais praticado no Brasil. 
MARCO A. D. TEIXEIRA

O país era, historicamente, deficitário na produção de empregos e postos de trabalho, com uma elite acostumada à escravidão e com leis trabalhistas recentes e precárias e servindo, apenas a trabalhadores urbanos, a Lei de Vadiagem, servia a senhores e agentes do Estado que, sob qualquer pretexto, podia deter e encarcerar cidadãos sem documentos e sem comprovação de trabalho fixo. Embora em desuso, tal lei ainda permanece ativa. De acordo com Villela (1941):

A definição de vadiagem e a sua punição estão previstas num artigo da Lei de Contravenções Penais, instituída por decreto em 3 de outubro de 1941. O artigo faz parte do capítulo VII da lei, que tem o sugestivo título "Das contravenções relativas à polícia de costumes". No seu artigo 59, a lei considera vadiagem "entregar-se alguém habitualmente à ociosidade, sendo válido para o trabalho, sem ter renda que lhe assegure meios bastantes de subsistência, ou prover à própria subsistência mediante ocupação ilícita". A pessoa classificada como "vadia" poderia ser levada à prisão simples, com pena de 15 dias até três meses. Na época da criação da lei, existiam a chamada Delegacia da Vadiagem e a figura do delegado de Costumes e Diversões.



Figura 3 - A divisão regional e territorial do Brasil entre 1940 e 1943/45

Fonte: IBGE apud Secretaria da Educação e do Esporte do estado do Paraná (website)

Migrando dos sertões e agrestes nordestinos, os trabalhadores do semiárido eram enviados para a Amazônia, superúmida e insalubre. Ignorando a realidade humana local, acreditavam, como diziam os intelectuais do regime Vargas, estarem se deslocando para uma terra vazia, que os esperava de abraços abertos, pronta para a colonização. Ao chegarem a seus destinos, esses trabalhadores deparavam-se com um sistema altamente coercitivo e militarizado de exploração de trabalho e mão-deobra, violentos conflitos étnicos e raciais, violência rural aguçada e espaços urbanos reduzidos e, fortemente, controlados pelas elites residentes. 
$\mathrm{Na}$ verdade, como ressaltam diversos autores, Albuquerque (1999) Lacerda (2006); Buriti e Aguiar (2008), Borzacov (2012), Lima (2013), a seca sempre foi apresentada como o mote de desencadeamento de processos migratórios de grande porte no Nordeste. A seca tornou-se um problema a partir da dramática estiagem de 1877 quando construiu-se tanto um imaginário da seca, associando-se o nordestino à pobreza e fome permanentes, quanto uma indústria capaz de carrear milhões e milhões em moedas nacionais e internacionais em obras contra a seca, que nunca cumpriram seu papel em ajuda humanitária e, nunca produziu a transformação das estruturas sociais, perpetuando o mando senhorial e a noção de caridade como forma de solução dos problemas oriundos dos abismos socioeconômicos que marcaram a história nacional. Como ressaltam Buriti e Aguiar:

\begin{abstract}
A partir da seca de 1877 e durante todo o final do século $\mathrm{XX}$, quando o Nordeste passou a ser significado como "região-problema" no cenário nacional, diversas destas propostas de "solução contra os efeitos das secas" passou a ser defendida pelos grupos de poder político e econômico dessa configuração territorial, entre eles a migração ou evacuação do espaço em busca de lugares com clima "sadio". Os destinos dos migrantes nesse momento eram variados: ora para outras províncias, especialmente para a Amazonas, o Pará ou as colônias agrícolas que seriam fundadas em regiões de clima mais ameno no Meio Norte, sobretudo, no Maranhão e Piau. Foi a partir desse período que a floresta amazônica passou a ser palmilhada pelos sertanejos do Nordeste; ora para as regiões de Brejo ou para as zonas litorâneas da própria região, áreas menos suscetíveis à escassez de chuvas (BURITI e AGUIAR, 2008, p. 11).
\end{abstract}

Vale ressaltar que, mesmo sendo a seca, o elemento dominante no imaginário social, como motor que desencadeia a migração nordestina, outros fatores devem ser considerados como de igual relevância: concentração fundiária, concentração das propriedades hídricas, subalternização do camponês, que se vê completamente impossibilitado de conquistar qualquer forma mínima de bem-estar ou alguma acumulação.

Os próprios mandatários e as elites locais, mesmo temendo as desordens, saques e crimes que os retirantes da seca poderiam provocar, eram conhecedores de que as políticas de emigração produzidas pelo governo nacional contribuíam para empobrecer ainda mais a região, privando as lavouras dos latifúndios da mão-de-obra barata representada pelos camponeses. Dessa forma, governantes locais criavam obstáculos à emigração, como ressalta Lacerda (2006, p. 135). Por outro lado, nos centros urbanos prevalecia o temor da desordem causada pelos flagelados. Assim o senador cearense D’Ávila, presidente da província, escreveu em seu relatório ao 
governo imperial, em 1889: "a degradação moral causada pela pobreza, anda a par com a depravação nascida de uma vida ociosa às custas da sociedade", mostrando a necessidade de impedimento das migrações e ao mesmo tempo, de ocupar, de forma útil, o trabalhador.

O poder nacional, consolidado após o golpe de Getúlio Vargas em 1937, promoveu a formação de um estado autoritário e truculento, que reprimia as oposições de forma violenta e se apresentava de forma paternalista aos trabalhadores urbanos em troca de sua sujeição e docilidade ao regime. O Estado Varguista, sobretudo na fase do Estado Novo (1937/45) remodelou a própria ideia de Nação, dando-lhe uma configuração pacificada e gentil, negando ou omitindo do passado histórico as tensões sociais e criando uma ideia de uma sociedade harmoniosa, multirracial e pluriétnica. Controlando a intelectualidade, perseguindo as vozes e mentes opositoras acima dos limites da lei, silenciando e controlando a imprensa e contando com uma força policial, militar e social a seu favor, Vargas viu, nas necessidades dos "Aliados" da Segunda Guerra Mundial, uma oportunidade de avançar seus projetos de poder e reorganização do Estado, dos espaços, fronteiras, economia e sociedade. Assim, foi, que, com os "Acordos de Washington" (1942), Vargas deu início a uma intensa política de deslocamento de Nordestinos para a Amazônia. A região era, então, considerada despovoada e, de acordo com as autoridades brasileiras e norte americanas, precisaria, de pelo menos 100.000 novos trabalhadores destinados imediatamente aos seringais. Essa mão-de-obra não estava disponível nos estados produtores de seringa, mas era abundante e ociosa no Nordeste.

É, portanto, em uma situação de total autoritarismo e centralização do poder que Vargas deu início ao processo migratório dos soldados da borracha para toda a Amazônia, concentrando o maior número possível de trabalhadores do sexo masculino, em idade de produção, em centros de embarque nas cidades litorâneas do Nordeste e, outros, de desembarque nos portos fluviais das cidades amazônicas.

Segundo Lima (2013, p. 48), o governo Vargas estimava que existiam na Amazônia brasileira, cerca de 300 milhões de pés de Seringueira (Hevea brasiliensis) em fase produtiva, o que asseguraria uma produção anual de 800.000 toneladas de borracha ao ano, mais do que o suficiente para atender aos Aliados e suas indústrias no período da Guerra (19139/45). 
No entanto, seria necessário reativar toda a cadeia produtiva, estagnada desde 1912, quando os seringais ingleses da Malásia passaram a dominar os mercados e a borracha brasileira desvalorizou-se. A esse mesmo tempo, o governo Vargas estimava que restavam, em toda a Amazônia, entre 30.000 e 35.000 seringueiros em atividade e que, para a produção imediata de 50.000 toneladas anuais, seria necessário um reforço, adicional, de mais outros 100.000 seringueiros em toda a Amazônia. Para concretizar esta meta, o governo norte americano investiu cerca de $\$ 2.750 .000,00$ dólares (LIMA, 2013, p. 50-51) e o governo brasileiro curvou-se ao seu papel histórico de intermediar a exploração barata da mão-de-obra nacional e da exportação de matérias primas.

Imediatamente, o governo Vargas assumiu as responsabilidades de deslocamento e assentamento dos migrantes nordestinos. Todo tipo de ideia surgiu, desde as mais sérias que pretendiam organizar e humanizar a migração, até as mais estapafúrdias, como ressaltou Lima (2013, p. 52) O Jornal "O Acre" chegou a noticiar o lançamento de seringueiros paraquedistas nas selvas brasileiras, a fim de que abrissem pistas de pouso para que aviões pudessem chegar repletos de seringueiros aos seus destinos.

Em novembro de 1940, Getúlio Vargas visitou a Amazônia e no dia 10, em Manaus, proferiu o celebre Discurso do Rio Amazonas, comprometendo-se a trazer o progresso, a civilização, o trabalho e a disciplina produtiva para essa região equatorial, tida como selvagem e insalubre. Neste mesmo discurso, o presidente falou da necessidade de trazer, para a Amazônia, um povo capaz de arrancá-la de seu estado primitivo e torná-la produtiva e próspera, enriquecendo, dessa forma, todo o Brasil. Seu discurso é pautado pelo autoritarismo, pela valorização do próprio governante, como o agente capaz de transformar a realidade e pela necessidade de sujeição e obediência das massas, de forma uníssona, para que tal destino pudesse se concretizar. Muito mais tarde, os governantes nacionais, em novo período ditatorial, nas décadas de 1960 e 1970, repetiram tais promessas e, em grande parte abandonaram a população migrante à sua própria sorte, à margem de estradas como a Transamazônica, semelhante ao que o ditador do Estado Novo havia feito com os soldados da borracha em 1945.

De acordo com Vargas, somente um povo seria capaz de colonizar e transformar a Amazônia e, esse povo, viria do Nordeste brasileiro. Os sertanejos, 
trabalhadores e resistentes, incansáveis e capazes de enfrentar todas as adversidades eram os escolhidos do Estado para essa tarefa quase sagrada de ocupar e fazer produzir todo o vale amazônico.

A Guerra Pela Borracha iniciou-se em 1943 e trouxe para a Amazônia mais de 70.000 "soldados da borracha". Um grande desconhecimento ainda paira sobre o tema, conforme ressaltam Lima (2013, p. 53 e seguintes) Souza (1977, p.17) e Pinheiro (2003). A partir de então, pairou no imaginário nacional a ideia, intencionalmente criada pelo Estado, de uma Amazônia despovoada e aberta à conquista, ao butim e à colonização.

Os novos seringueiros deveriam adotar uma postura militarizada, condizente com o modelo do Estado Novo. Não seriam apenas trabalhadores, mas soldados a serviço da pátria, serviriam aos esforços de guerra em outro front, a floresta amazônica. É interessante observar que o Brasil perdeu 450 praças, 8 pilotos e 13 oficiais nos campos de guerra na Itália, entre 1944 e 1945.

No entanto, morreram mais 20.000 soldados da borracha, entre 1943 e 1945, nos seringais amazônicos. Segundo Guillen:

Estima-se em cerca de vinte mil os migrantes que morreram nos seringais, mortes provocadas principalmente pela malária e pela fome, segundo dados divulgados pela comissão de inquérito da Assembleia Constituinte em 1946, que averiguou os resultados da Batalha da Borracha (GUILLEN, 1997, p. 100)

A viagem, desde seus locais de origem até os confins da floresta, nos seringais de toda a Amazônia, era demorada e cheia de percalços. Brigas internas dentro das embarcações, confusões em cada porto de desembarque, doenças, péssimas acomodações e total controle do Estado sobre os indivíduos faziam parte do processo.

Ao chegarem nas localidades amazônicas, voltavam a ser internados em campos de pousio, até serem escolhidos pelos agentes dos seringais. Deveriam permanecer nos seringais pelo período contratado e depois, segundo os agentes de alistamento, receberiam recursos e passagens de retorno. Essas promessas nunca foram cumpridas.

Chegando aos seringais, os soldados da borracha estavam a serviço da Pátria, mas sob as ordens severas e personalistas, de um seringalista que os exploraria aos limites de suas forças. Os regulamentos de cada seringal tinham normas próprias e muito brutais. O próprio Estado, ainda mal saído da escravidão, praticava toda a sorte de abusos, como foi o caso do leilão praticado em 1912, em Santo Antônio do Madeira, 
onde a chefia de polícia do município de Santo Antônio do Madeira, em nome do governo nacional, leiloou 400 homens, em sua maioria negros, condenados, anistiados e mesmo assim, presos e embarcados no navio Satélite, juntamente com 40 mulheres, tidas como prostitutas do cais do Rio de Janeiro e um único homossexual, também embarcado por ser considerado um problema para a ordem na capital da República. Tal fato é citado em Citado em: Rui Barbosa (1919), Obras Completas; Francisco Foot Hardman (1991), O Trem Fantasma e a Modernidade na Selva, Amizael Gomes da SILVA (2001), Da Chibata ao Inferno.
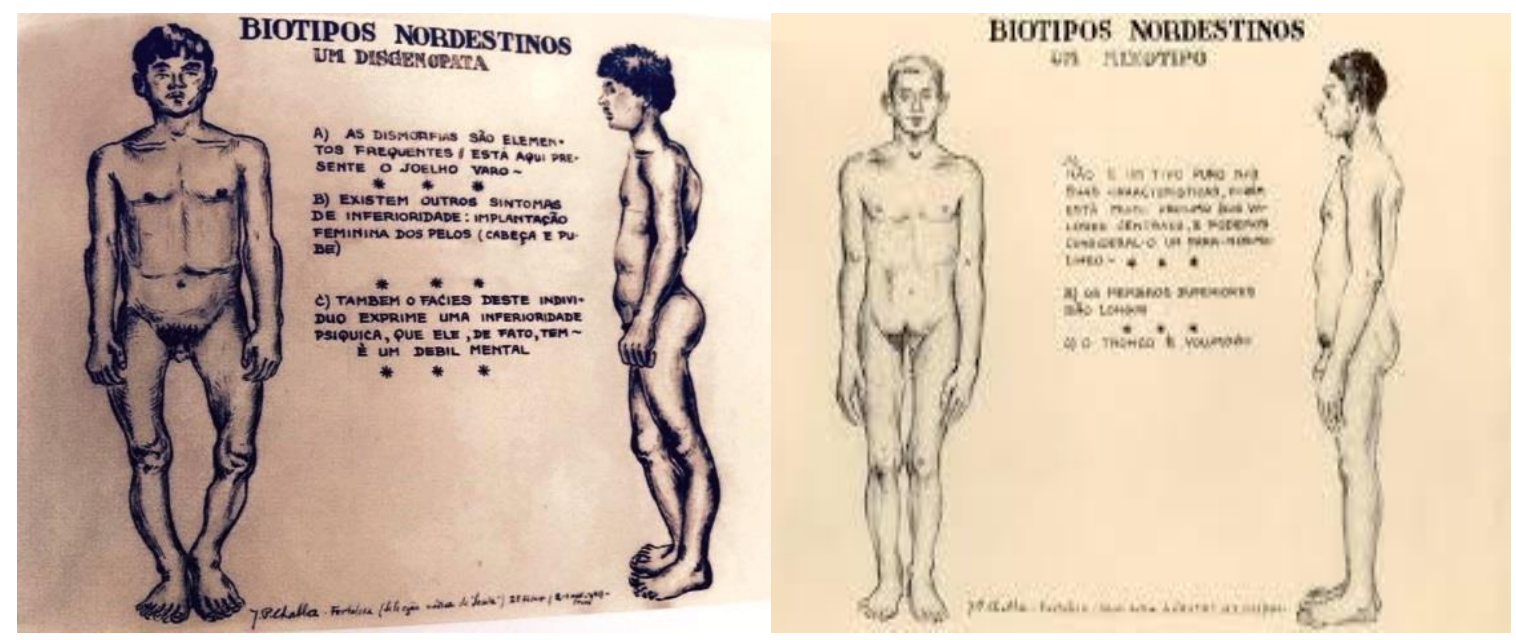

Figura 4: Biotipos nordestinos

O Estado Varguista adotou as práticas raciais vigentes na Europa. Buscava-se o tipo brasileiro ideal. Assim, os Nordestinos embarcados para a Amazônia eram classificados em três categorias conforme sua compleição física: Mixotipo, Brevilíneo e Disgenopata.

Fonte: Gianotti (2016, p 96)

O regime de trabalho dos migrantes "escolhidos" para os seringais beirava a escravidão, havendo escolhas, nos campos de pousio ou pouso, que lembravam a compra de escravos. Borzacov (2012) escreve que:

Eles eram reunidos nos barracões, no local onde é hoje o Quartel do $1^{\circ}$ Batalhão da Polícia Militar, e os seringalistas examinavam suas pernas. Se fossem grossas, eram rejeitados. Pernas finas eram o indício peculiar que 0 nordestino seria bom seringueiro, saberia abrir "estrada" e percorrê-la todos os dias na coleta do látex. Comentava sorrindo que os candidatos à seringueiros, pernambucanos e paraibanos não eram bem aceitos, tinham fama de brigões.

\section{A trajetória}

Paralelamente ao projeto migratório, Vargas avançou no projeto de criação de novas unidades federais, criando os Territórios Federais do Guaporé (hoje Rondônia), 

Sul), Iguassu (hoje integrado ao Paraná) e Fernão de Noronha (hoje integrado ao estado de Pernambuco)

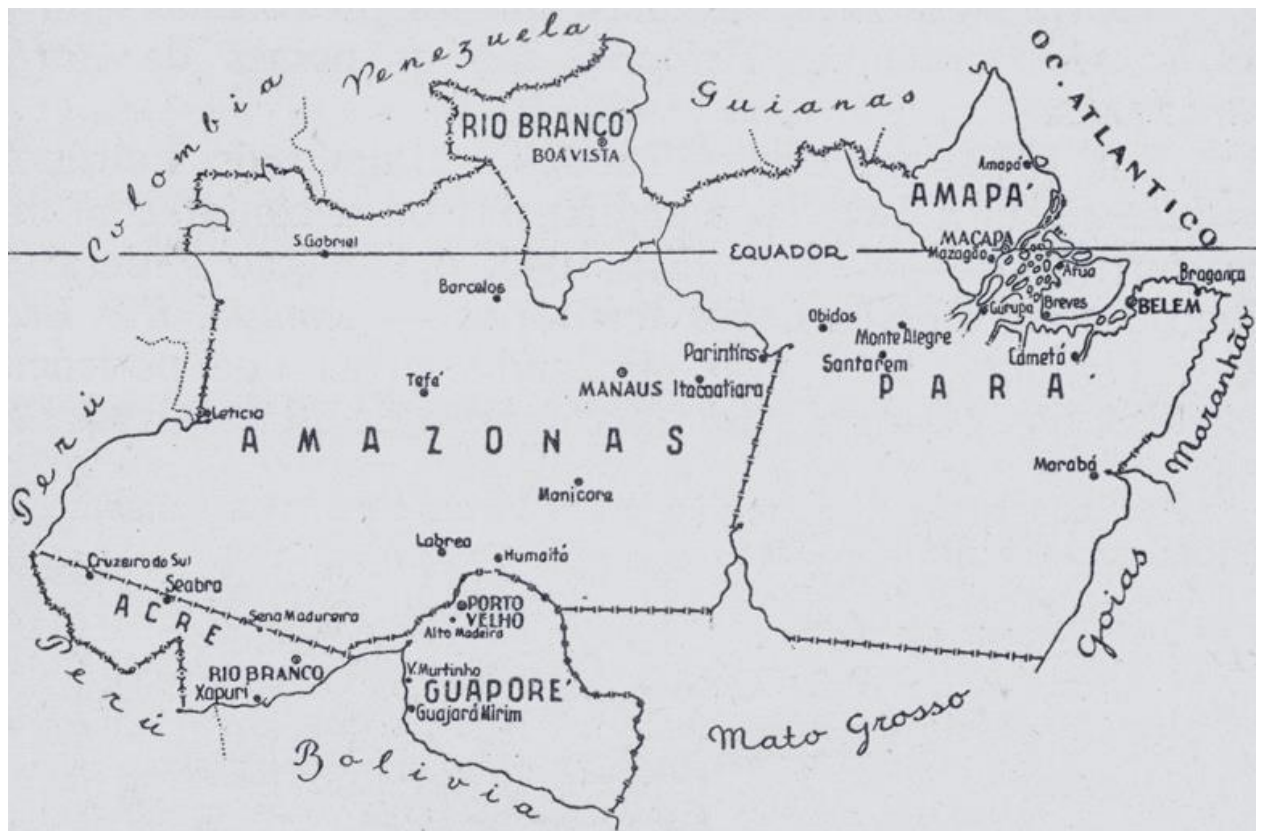

Figura 5 - A Nova Divisão Territorial da Região Norte, criada por Getúlio Vargas em 1943.

Fonte: Guia Geográfico da História do Brasil. Disponível em: http://www.historiabrasil.com/mapas/brasil-1944.htm Data de acesso: 02/07/2019.

A viagem entre os locais de origem e de destino era marcada pelo medo e pelos processos de disciplinarização. No dizer de Vargas, essa migração era, agora, uma estratégia de guerra e uma ação militar. O Estado apropria-se do discurso religioso, comparando os migrantes aos judeus em êxodo no deserto, conduzidos pela sabedoria e pela força de Moisés, mas apropria-se igualmente da tarefa de liderar, de forma totalitária e absoluta, todo o processo, definindo quem embarca e para onde vai.

Verônica Secreto (2007, p.37) estima em mais de 50.000 pessoas, o número de migrantes que vieram do Nordeste para a Amazônia, entre 1941 e 1945, a maioria desses como soldados da borracha (1943/45). Desse total, a maior parte destinou-se ao Amazonas e Pará, mas um grande contingente foi enviado para os Territórios do Guaporé, Amapá e Estado do Acre.

As viagens se davam por diversos motivos, medo de ser alistado para os fronts de guerra na Europa, pressão exercida pelas adversidades ambientais, aliciamento dos agentes encarregados dos alistamentos voluntários, pressões familiares, atração 
diante da possibilidade de se tornar um proprietário em uma localidade sem secas e sem senhores, etc.

Lima (2013) reconhece outros fatores que estimularam as migrações dos nordestinos para a Amazônia, inclusive a resistência diante das adversidades, ao tomarem para si a decisão de migrar, os soldados da borracha buscavam novas oportunidades de reconstruírem as próprias vidas e criarem oportunidades em novos locais. Ainda segundo Lima:

o primeiro órgão estatal a ser institucionalmente responsabilizado por tal deslocamento foi o Departamento Nacional de Povoamento (DNP), que, em 1938, passa a se chamar Departamento Nacional de Imigração (DNI). Em 30 de novembro de 1942, foi criado o Serviço Especial de Mobilização de Trabalhadores para Amazônia, o SEMTA. (LIMA, 2013, p. 71).

Pelos Acordos de Washington, o governo brasileiro deveria enviar, para a Amazônia, cerca de 50.000 homens em idade produtiva, aptos a todos os trabalhos em um seringal, até maio de 1943. O processo de alistamento e embarque dos soldados da borracha foi marcado por diversas formas de resistência e negociação com os agentes governamentais.

Após o cadastramento, os grupos alistados eram mantidos em campos de pouso, cercados e vigiados, aguardando o deslocamento. Os campos tinham uma estrutura higienista e, altamente reguladora, e neles os futuros soldados da borracha passavam o dia ocupando-se, de forma próxima ao militarismo, em atividades diversas como a prática de exercícios físicos calistênicos, aprendizado teórico para o plantio, corte e defumação da seringa, apoio espiritual, avaliação médica, trabalhos braçais e disciplinarização militar, com horários rígidos para todas as atividades. Tais campos eram chamados pelo SEMTA de pontos de concentração. Os alistados deveriam estar uniformizados como soldados da borracha e manter valores militares em seu comportamento (Lima, 2013, p. 78 e seguintes). A colaboração no esforço de disciplinar, instruir, preparar e subordinar os homens, contava com os esforços adicionais das polícias e do próprio Exército. A disciplina incluía a realização de todo tipo de trabalho, enquanto o indivíduo estivesse sob o "abrigo do campo de pouso." Nesta condição, eram embarcados, quase sempre à noite, marchando, em fila e sob guarda armada, até os navios que os levariam para a Amazônia.

Abnael Machado de Lima (2017), lembra que o trajeto era conflituoso, cheio de ansiedades e medos, marcado, pelos rigores das autoridades e do próprio confinamento, por meses, em um navio. "Ao chegar em cada ponto de desembarque, 
eram acompanhados po forças policiais armadas, que os conduziam ao novo campo de pouso, enquanto aguardavam pela escolha de seus novos patrões, para o trabalho em alguma "colocação".

Ao desembarcarem, os "soldados da borracha", eram alojados em novos campos de pouso ou pousio. De forma militarizada, os migrantes marchavam dos portos de desembarque até os alojamentos de espera, que se configuravam em campos cercados e guardados por policiais ou militares armados. Os abrigos eram construídos sob a forma de grandes galpões de madeira, semiabertos e com cobertura de palha. Ali os soldados da borracha deveriam armar suas redes, cuidar de seus parcos pertences e, quando sabiam ler, tomar conhecimento das instruções e orientações dadas pelos serviços governamentais, como o SAVA (Superintendência de Abastecimento do Vale Amazônico), SEMTA e o CAETA.

A higiene era norma sanitária e uma grande preocupação médica. As novas noções de higiene e cuidados do corpo, do asseio e do local, eram tratadas sob o olhar vigilante dos administradores de cada campo e pelos encarregados e controle sanitário locais. Não havia sistema de esgoto, mas banheiros fechados para esconder latrinas eram eficientemente erguidos. Conforme narra Rios $(2014,121)$, o local de realizar as necessidades fisiológicas dos sertanejos era o próprio quintal, ou arredores da casa. Esse costume foi duramente combatido pelos sanitaristas, que impuseram a norma da vergonha diante da realização de atos ligados às necessidades fisiológicas como norma; deveriam ocorrer em espaço fechado, isolado e distante.

Os banheiros tornaram-se locais marcantes no processo de disciplinarização e submissão dos sertanejos. Chegavam, mesmo, a receber nomes de honra, de acordo com algum filantropo que se dispusesse a custeá-lo. O banho tornava-se obrigatório, deixava de ter um aspecto lúdico e de lazer e passava a vigorar como norma sanitária. Deveria ser tomado ao iniciarem-se as atividades do dia, normalmente às cinco horas da manhã. O uso do sabão, era obrigatório e constituía-se numa das regras higienistas da época. Conforme lembra Abnael Machado de LIMA: "Todo mundo era limpo e tinha seus pertences sempre organizados e prontos para a partida" (Entrevista, 2017).

As cozinhas deveriam ser bem mantidas pelos próprios trabalhadores e uma das grandes possibilidades de ascensão social consistia em trabalhar com os alimentos. Havia pátios para exercícios, previamente definidos pelos agentes de controle, barracas de enfermaria e locais de aprisionamento para os desordeiros. $O$ 
tempo e os horários para cada atividade eram rígidos e deveriam incutir um novo sentido à existência. A vida deixaria de ser vivida segundo as estações do ano e passaria a ser regida pela disciplina matemática do trabalho. Normalmente, os dias começavam com os banhos frios, ao romper das primeiras luzes da aurora e terminavam com a última refeição, ao cair da noite. Porções de alimentos, de material para higiene e de vestimentas eram meticulosamente calculadas.

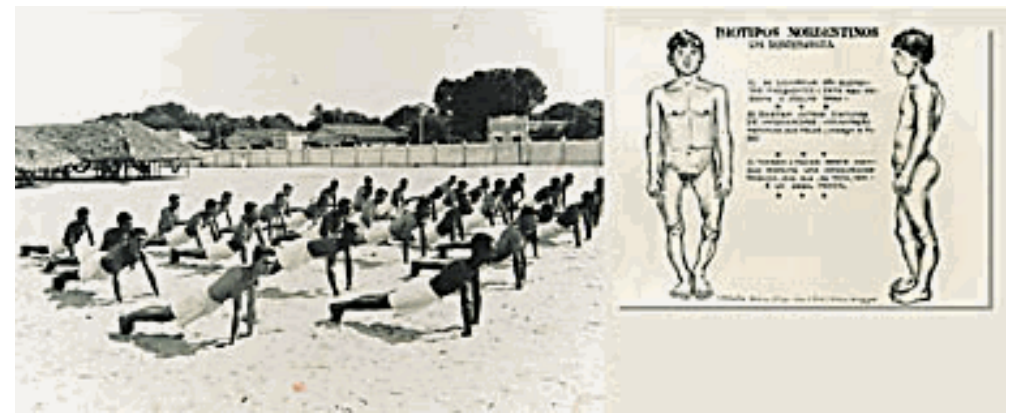

Figura 6. Arigós concentrados em campo realizando exercícios calistênicos. Observe-se ao fundo a cerca do campo e os barracões de alojamento. Fonte: Reproduções: Museu do MAUC apud Seringal Guapimirim. Disponível em: <http://seringalguapimirim.com.br/a-batalha-daborracha.html>

Os campos possuíam guarda externa armada, para impedir fugas ou invasões, guarda interna para a disciplinarização dos abrigados. Membros dos grupos reclusos nos campos eram selecionados para atividades especiais, criando hierarquias internas, gerando novas e capilarizadas redes de poder, mando e subalternização. Aos trabalhadores escolhidos para as mais diversas funções era pago um pequeno salário, que ampliava as disputas internas e reforçava o valor da ordem, da disciplina e da subalternização como meios de ascensão social. Essa estratégia mantinha os grupos divididos e incitava ao colaboracionismo.

Os homens que migravam eram, em sua maioria, jovens em pleno vigor físico. A idade, segundo narradores, como Matias Mendes e Abnael Machado de Lima (2017), variava de 18 a 25 anos. A maioria dos que chegaram entre 1943 e 1945, vieram sozinhos, o que provocava grave desequilíbrio entre os sexos nas localidades em que se instalavam. Muitos desses homens traziam bonecas de pano para terem alguma companhia feminina nas colocações em que viveriam.

Ao desembarcarem nas cidades que os acolheriam, temporariamente, sempre que possível, buscavam aventuras, romances, bares periféricos, locais para alimentação e, não raro, metiam-se em confusão. As notícias de suas altercações e confusões precediam-nos e causavam clima de pavor nas sociedades que estavam 
no roteiro dos navios. Daí a necessidade considerada pelas autoridades da época de criar locais de confinamento, como meio de garantir a estabilidade social. Em Porto Velho, o ponto de concentração dos soldados da borracha foi chamado, de forma pejorativa, Arigolândia, a terra dos Arigós. Ficava distante, algumas centenas de metros das residências urbanas do Caiari e do centro da cidade.

\section{A cidade de Porto Velho: das origens à Guerra pela borracha.}

Porto Velho é a capital do Estado de Rondônia. Atualmente conta com uma população aproximada de 519.531 habitantes, segundo dados do IBGE/2018. A cidade está localizada na margem direita do rio Madeira, sete quilômetros abaixo da cachoeira de Santo Antônio, onde foi construída a Hidrelétrica de Santo Antônio.

A região foi local de moradia de muitas etnias indígenas ao longo do século, em especial os povos Mura, Karitiana, Kaxarari e Karipuna são mencionados ao longo da história de formação da localidade. As terras de Porto Velho eram cobertas pela densa floresta amazônica e nela situavam-se extensos seringais.

A ocupação colonial é relatada desde o século XVII, quando um padre jesuíta, João Sampaio, tentou fundar a Missão de Santo Antônio do Rio Madeira, em 1722. Ao longo da segunda metade do século XIX, a região vivenciou importantes episódios ligados ao ciclo da borracha. Na década de 1870, empreendimentos ingleses e norteamericanos marcaram as primeiras tentativas, malfadadas, de construção da Estrada de Ferro Madeira-Mamoré/EFMM. As condições ambientais, a adversidade climática e a hostilidade dos povos indígenas inviabilizaram as primeiras tentativas de construção e somente em 1907, houve uma retomada do projeto de construção da EFMM.

Naquele ano, a Madeira-Mamoré Railway Company, que detinha a concessão para a construção da ferrovia determinou, que o empreendimento não teria seu ponto inicial em Santo Antônio do Rio Madeira, situado, então, no estado de Mato Grosso, mas em um ponto localizado alguns quilômetros rio abaixo, denominado Porto Velho, pertencente ao estado do Amazonas.

Porto Velho recebe seu nome devido a existência de um antigo porto fluvial, construído na década de 1860 pelos militares do império brasileiro, como forma de assegurar a ligação com a província do Mato Grosso, então ameaçada pelas forças de Solano Lopez, durante a Guerra do Paraguai. 
Surgida a partir de um pátio de obras ferroviárias, Porto Velho teve como seu primeiro bairro popular o Triângulo. Nele residiam os funcionários menos graduados da Madeira-Mamoré. A cidade era dividida em duas partes, separadas por uma cerca até o ano de 1915. Do lado oeste da cerca ficava a cidade ferroviária, controlada pela empreiteira norte-americana Madeira and Mamoré Railway Company. Essa era uma cidade estritamente funciona, asséptica e disciplinada pela ótica da produção capitalista.
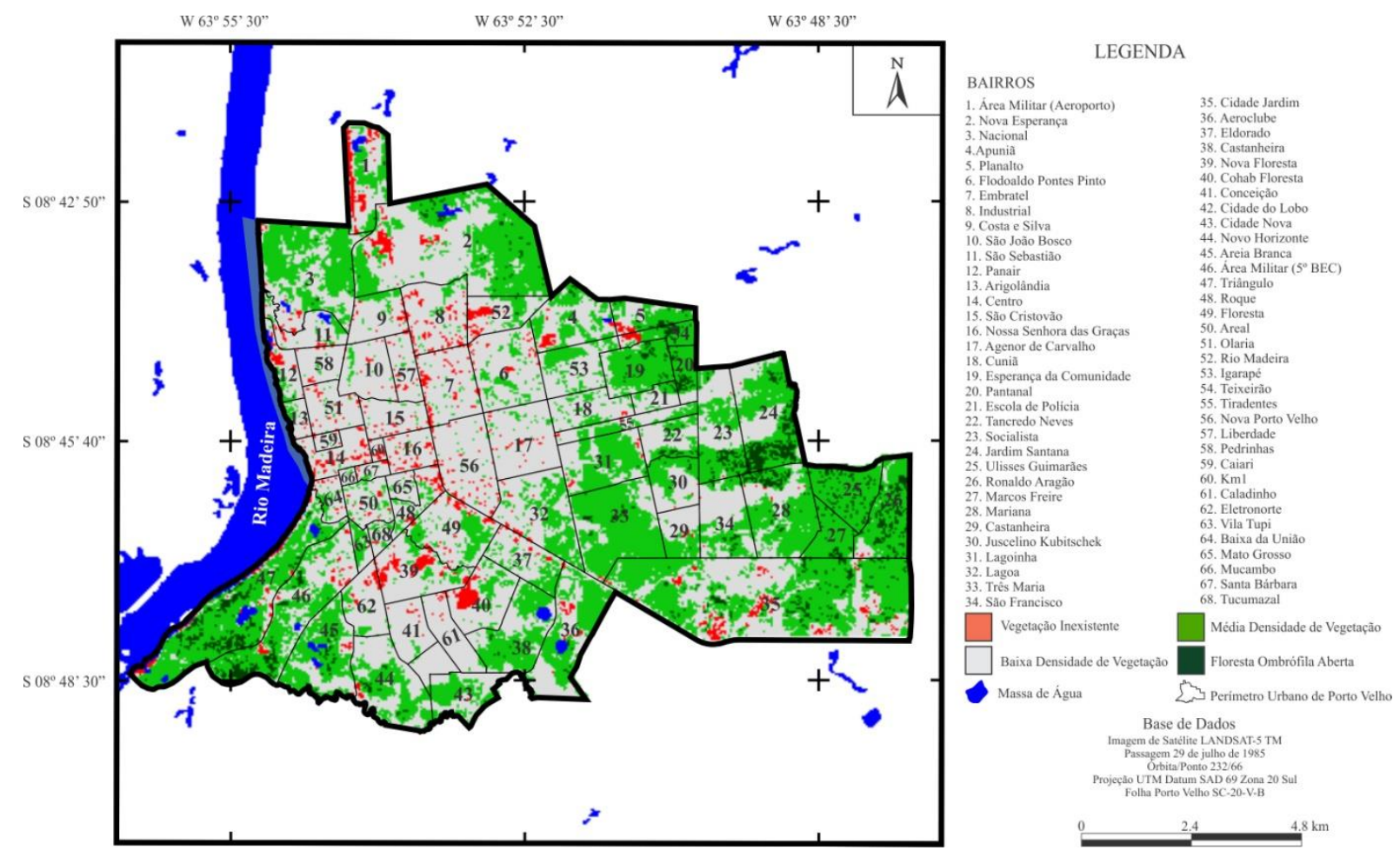

Figura 7. Mapa dos bairros de Porto Velho.

Na legenda, sob o número 13, pode-se ver o bairro Arigolândia. Fonte: https://journals.openedition.org/confins/docannexe/image/12191/img-7.jpg

Construída em modelo padrão dos empreendimentos norte-americanos da época, essa parcela da cidade contava com energia elétrica, água tratada, fábricas de gelo e de biscoitos, moradias padronizadas para funcionários graduados e áreas adicionais onde os funcionários menos graduados podiam erguer suas residências. Havia uma direção administrativa da ferrovia, um clube de laser, um hospital para doenças tropicais, que atendia aos ferroviários e um cemitério. Neste mesmo espaço, controlado pela empresa norte americana, ficava o porto fluvial do Cai N'Água, então única porta de acesso à cidade.

Para além da linha divisória, cerca de 300 metros para leste do rio Madeira, erguia-se a cidade brasileira, uma outra Porto Velho, construída em palha e madeira 
bruta, sem nenhuma comodidade. Seu primeiro bairro chamou-se Mocambo e era considerado um local de extrema periferia. Ao mesmo tempo outras áreas começavam a ser habitadas; o Alto da Favela, o Centro, a ladeira Comendador Centeno, o Caiari e, no início dos anos 1940, a Arigolândia.

A cidade era conhecida por sua insalubridade. Somente nos anos de construção da ferrovia Madeira-Mamoré (1907-1912), morreram 6500 trabalhadores e cerca de 10.000 Karipuna (TEIXEIRA E FONSECA, 1998). Em 1914, a localidade amazonense de Porto Velho foi elevada á condição de município, tendo como seu primeiro superintendente o Major Fernando Guapindaia, que logo entrou em atrito com a administração da ferrovia, ao mandar derrubar a cerca que separava as duas áreas da cidade.

O município de Porto Velho foi criado através da Lei no. 757, sancionada pelo governador do estado do Amazonas, Jonathas de Freitas Pedrosa. Em 1915, chegou a Porto Velho e tomou posse no cargo de intendente municipal o Major de Engenharia do Exército Fernando Guapindaia. Desse período até 1924, o governo municipal foi exercido por superintendentes e o Poder Legislativo pelo Conselho Municipal, composto por intendentes. Em 1919, Porto Velho é elevada à categoria de cidade pela Lei 1011, de 07 de setembro de 1919, assinada pelo governador do Amazonas, Pedro de Alcantara Bacellar. A partir de 1924, com o estabelecimento do governo revolucionário no Amazonas, o município de Porto Velho deixa de ter seu poder legislativo, situação que se mantém com a Revolução de 30 e prolonga-se até 1969, quando os municípios dos territórios federais passam a possuir Câmaras de Vereadores (TEIXEIRA e FONSECA, 1998, p. 147).

Na década de 1940, a cidade tornou-se um importante centro de desembarque de nordestinos alistados pelo governo Vargas na Guerra pela Borracha. Seu trabalho seria requisitado nos seringais locais, na construção civil das edificações urbanas, na manutenção da ferrovia Madeira-Mamoré, no porto do Cai N'Água, nas colônias agrícolas criadas ao longo do eixo ferroviário, em colônias de pescadores, na mineração, na educação e nas artes da cidade.

Como ponto principal de concentração e dispersão dos nordestinos embarcados para o Território Federal do Guaporé, os arigós, que chegavam a Porto Velho, na década de 1940, eram confinados no ponto de concentração denominado Arigolândia. Ali eram mantidos até serem enviados aos seringais. Alguns, no entanto, 
permaneceram na área urbana, prestando todo tipo de serviços, tanto ao campo de pousio, quanto às autoridades e à população local.

Até meados do século XX, a cidade manteve-se dentro de um quadrilátero de $5 \mathrm{~km}$. Após os anos 1960, seu crescimento tornou-se acelerado e a população que, na década de 1930 chegava a 3.000 habitantes passou 27.224 habitantes no censo de 1950, o primeiro realizado em Porto Velho e, a mais de 138.289 habitantes, ao final dos anos 1980 (IBGE, 2019). O então Território Federal do Guaporé contava com apenas dois municípios: Porto Velho e Guajará-Mirim.

O bairro da Arigolândia localiza-se ao norte do que era a pequena cidade de Porto Velho. No início dos anos 1940, de acordo com Abnael Machado de LIMA (entrevista realizada em abril de 2017), era apenas uma extensão de matas secundárias e grandes capoeiras. Ali se criavam animais, mas a região era próxima ao rio, com barrancos altos e salubres. No entanto ficava distante o suficiente do núcleo central da cidade, onde viviam as famílias ferroviárias e a administração do território. A cidade mantinha-se ativa através dos trabalhos dos ferroviários, do nascente funcionalismo público e como ponto comercial importante, capaz de abastecer o alto Madeira, o vale do rio Machado, o Mamoré e o Guaporé.

\section{O Nordestino entre o seringal e a cidade}

Sem embargo, podemos dizer que os nordestinos de diversos estados formaram a base da população portovelhense. Sua presença já era registrada na história local desde o século XIX, meio século antes da fundação do município. Neville Craig (1940) fala da grande quantidade de nordestinos mortos nas primeiras tentativas de construção da ferrovia Madeira-Mamoré, na década de 1870.

A vinda de migrantes nordestinos para a região do Madeira, Mamoré e Guaporé, além do Machado, Jamari e outros ocorreu a partir do século XIX, com o auge da borracha. Do último quartel daquele século, até os dias atuais, a migração nordestina para a região foi contínua e definiu, em grande parte, a colonização e a cultura do município. Nordestinos vieram como seringueiros e soldados da borracha, mas vieram, ainda, como garimpeiros, colonos agrários, comerciantes, funcionários públicos e mão-de-obra urbana para todos os tipos de serviço. Diversos bairros da cidade de Porto Velho têm sua origem, fundação e história associada a essa migração. Dentre todos os bairros locais, no entanto, destaca-se o bairro da Arigolândia. 
Os nordestinos chegavam a Porto Velho a bordo de navios do SNAPP (Serviço de Navegação da Amazônia e de Administração do Porto do Pará). Ao desembarcarem no Porto do Cai N'Água, os soldados da borracha, marchavam perfilados até o campo de pouso denominado Arigolândia, que havia sido construído com recursos da SAVA, regionalmente chefiada pelo paraense, Aluízio Ferreira, primeiro governador do Território Federal do Guaporé. Para a construção do Araçazal, foi escolhida a área denominada Araçazal, ao norte da cidade, distante o suficiente do centro e das áreas povoadas pelas classes dominantes.

O responsável pela construção do campo foi o engenheiro agrônomo Edgar de Souza Cordeiro, que utilizou madeira local, palha e trilhos da EFMM que estavam em desuso. A limpeza do terreno foi realizada sob o comando do capitão Ênio Pinheiro, comandante da Segunda Companhia Rodoviária, mais tarde governador do Território. Para diretor do Campo da Arigolândia, foi nomeado o professor Enos Eduardo Lins, a ele cabia as tarefas de supervisão e controle do campo e dos homens ali alojados.

Borzacov (2019) escreve que, ao redor deste ponto de concentração, foram erguidas casas de madeira pré-fabricadas para abrigar os soldados da Guarda Territorial. Nessa região, concentravam-se os nordestinos, em um grande campo de pouso e a presença dos guardas era plenamente justificável. De acordo com Vitor Hugo (1959), em 1946, o bairro deixou de chamar-se Arigolândia, nome pejorativo e já não mais justificável, pois a Guerra pela Borracha havia terminado e foi, oficialmente, rebatizado como Bairro Nossa Senhora do Perpétuo Socorro, tendo sido erguida, de fronte para o rio Madeira, uma bela igreja em honra da Santa (HUGO, 1998, p. 507). Contudo, os moradores não aceitaram a mudança do nome do bairro. O nome "Arigolândia" foi mantido e a lei foi derrubada. 


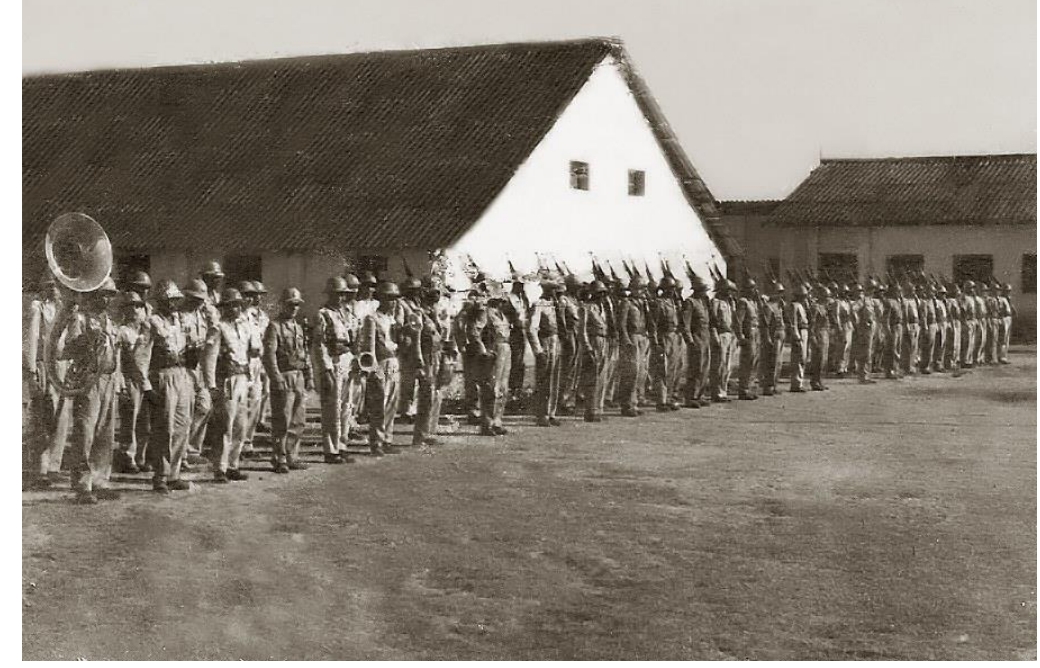

Figura 8. O Quartel da Guarda Territorial em Porto Velho.

O Quartel da Guarda Territorial em Porto Velho erguido no mesmo local e a partir das mesmas edificações do Ponto de Concentração Arigolândia, de 1944, na cidade de Porto Velho. Fonte: Arquivos do Saudosismo Portovelhense.

Borzacov (2016, p. 45) ainda explica que em 1944, o já governador Aluízio Ferreira, criou pelo Decreto № 1, de 11 de fevereiro de 1944, a Guarda Territorial, composta por quarenta guardas e seus comandantes. Pelo Decreto № 19 de setembro de 1944, foi criada a Banda da Guarda Territorial, composta por 25 músicos. Originalmente, a Guarda Territorial foi instalada em um dos casarões da EFMM, conhecido como prédio da Fiscalização. Com a desativação do Campo de Pousio da Arigolândia, o espaço foi remodelado e seus barracões, reformados, transformaramse no Quartel da Guarda Territorial.

Ao redor do campo, mais tarde transformado em Quartel, começaram a surgir casas de pequeno porte, em madeira e palha. A ampliação do desmatamento na beira do rio definiu o traçado das ruas e logradouros do bairro. A madeira utilizada para a construção das primeiras casas era constituída de refugos doados pela serraria Tiradentes (BORZACOV, 2014, p. 47). Com o passar dos anos e o crescimento da cidade, a Arigolândia passou da condição de bairro periférico, para a situação de um bairro de classe média. Ao seu redor foram construídos o Estádio Aluízio Ferreira, o Clube de Regatas Flamengo e as Escolas Carmela Dutra, Castelo Branco e Duque de Caxias.

Durante as primeiras décadas de sua existência, no entanto, a Arigolândia se constituiu em um bairro de moradores pobres, que prestavam serviços para o poder público e a iniciativa privada, ou mesmo, para casas e patrões em âmbito doméstico. 
De acordo com Centeno (2008) e Centeno e Teixeira (2008), de "arigós", seus moradores, passaram a ser conhecidos como "mundiças", uma nova categoria social pejorativa, que dominaria as relações sociais em Porto Velho pelos anos 1950 a 1970. Pobres, em geral, trabalhadores sem qualificação, aqueles que prestavam serviços ou possuíam pequenos comércios, mesmo os ambulantes, aqueles que viviam nos bairros periféricos, eram conhecidos por este apelido, que nas suas raízes significaria "imundices". Do lado oposto aos "mundiças" estavam os "categas", aqueles que tinham "categoria", eram servidores públicos, donos de terras, empresários bem sucedidos, e ocupavam postos de destaque na sociedade. Frequentavam os bailes do Porto Velho Hotel e habitavam o Caiari e o Centro.

A luta de classes, permanecia, mudando-se o rótulo dos agentes. Nordestinos continuaram a chegar e a Arigolândia, dos anos 1970 em diante, não mais os recebia. A eles eram destinados novos bairros, ainda em construção e sempre periféricos, localizados, principalmente, na zona Leste e na Zona Sul da Cidade. Sua importância, entretanto, pode ser percebida em diversos fatos, eventos e processos históricos que marcaram a trajetória histórica de Rondônia. É importante lembrar que a primeira mulher a ocupar o cargo de governadora de um estado no Brasil, foi uma paraibana residente em Porto Velho, cujo nome é Janilene Melo.

\section{Considerações finais}

Ainda hoje é subdimensionada a contribuição das populações nordestinas na formação do povo e da cultura de Porto Velho e de Rondônia. Sabe-se que suas migrações para a região antecedem a Guerra pela Borracha e continuam até os dias atuais. A cultura local é marcada por toda sorte de contribuição dessas populações. A sociedade, em grande parte, descende desses pioneiros. Seu trabalho pode ser visto em todos os detalhes da cidade e seus descendentes estão em todos os lugares e ocupam todo o tipo de postos hierárquicos, serviços, empregos e funções.

A memória da cidade ainda guarda as lembranças dos Arigós, soldados da Borracha que viveram e morreram por uma causa inventada pelo estado varguista, em sua ânsia de criar um país moderno, higienizado e ocidentalizado. Neste país, caipiras, sertanejos, caboclos e outros grupos étnicos deveriam ceder lugar á nova ordem e integrarem-se ao novo modelo civilizatório. 
Os arigós, migrantes, trabalhadores, desordeiros e resistentes transformaramse em mundiças e, hoje, integram toda a sociedade rondoniense, que thes deve grande parte do seu legado como povo.

O sertanejo soube resistir às adversidades da seca e às ciladas do Estado, que sempre viu neles a oportunidade de alavancar o capital, percebendo-os como mera mão-de-obra barata e acessível. Sem ter seus direitos plenamente reconhecidos, trapaceados, historicamente, pelo Estado e seus agentes, os Arigós sempre demonstraram resiliência e obstinação. Sobreviveram e mantiveram seus pertencimentos culturais, levando suas tradições para onde quer que fossem, sempre dispostos a conhecer e vivenciar as culturas dos lugares onde se instalaram.

A história dos nordestinos de Rondônia e suas contribuições e participações na construção dos espaços urbanos e rurais, ainda está por ser escrita. A cidade reconhece seu valor, mas o Estado ainda os percebe como os "mundiças" e os "arigós", negando-lhes o reconhecimento identitário e honorífico de heróis da Pátria e os méritos a que fizeram por merecer.

\section{Referências Bibliográficas}

ALBERTI, Verena. Manual de História Oral. Rio de Janeiro: FGV, 2004.

O que documenta a História Oral? Possibilidades para além da construção do passado. II Seminário de História Oral, FFCH/UFMG. Belo Horizonte, 1996. Disponível em: <https://cpdoc.fgv.br/producao intelectual/arq/869.pdf >. Acessado em 21 de março de 2019 .

ALBUQUERQUE JUNIOR, Durval Muniz de. A invenção do Nordeste e outras artes. São Paulo: Cortez Editora, 1999.

ARAÚJO, Ariadne e NEVES, Marcos Vinícius. Soldados da borracha, os heróis esquecidos. São Paulo: Editora Escrituras, 2015.

BARBOSA, Rui. Obras Completas de Rui Barbosa. Rio de Janeiro: Senado Federal 1914.

BORZACOV, Yedda Pinheiro. Os Arigós. In: Gente de Opinião. 23/12/2012. Disponível em: <https://www.gentedeopiniao.com.br/colunista/yedda-pinheiroborzacov/os-arigos>. Acessado em 10 de julho de 2019.

BORZACOV, Yedda Pinheiro. Os Bairros na História de Porto Velho. Porto Velho: Gráfica Comunicação e Cia, 2016.

. Porto Velho: 100 Anos de História. Porto Velho: IHG, IPARI, Primor, 2007. 
BOM MEIHY, José Carlos Sebe. Manual de História Oral. 5a Edição. São Paulo, Edições Loyola, 2005.

BOM MEHEY, José Carlos Sebe Bom e HOLANDA, Fabíola. História oral, como fazer, como pensar. São Paulo: Editora Contexto, 2018.

BURITI, Catarina de Oliveira Eaguiar, José Otávio. Natureza e cultura nos domínios de Clio: as secas e outras representações das paisagens semi-áridas na historiografia ambiental. In: Cadernos de História, Belo Horizonte, v.10, n. 13, 1ํs sem. 2008. Disponível em: <file:///C:/Users/user/Downloads/971-3255-1-PB\%20(1).pdf> Acessado em 2 de julho de 2019.

D’ÁVILLA, Henrique. Relatório que o Exmo. senhor Henrique D’Ávila, senador do Império e Presidente da Província do Ceará passou a administração desta Província ao Exmo Senhor. Fortaleza. Typographia Econômica, 1889. P. 6.

DICIONÁRIO INFORMAL. Arigó. Disponível em: <Disponível em: https://www.dicionarioinformal.com.br/arig\%C3\%B3/2/>.

FOUCAULT, Michel. Microfísica do Poder. São Paulo: Graal, 2005.

GIANNOTTI, Carlos Ugo. A saga dos soldados da borracha. O Brasil na Segunda Guerra Mundial. Goiânia, Kelps, 2016.

GOMES, Paulo C. da C. O conceito de região e sua discussão. In: CASTRO, Iná E.; GOMES, Paulo C.; CORRÊA, Roberto L. Geografia: conceitos e temas. Rio de Janeiro, Bertrand Brasil, 2003, p. 49-76

GUILLEN, Isabel Christina Martins. A batalha da borracha. In: Revista de Sociologia e Política No 9. Recife: Fundação Joaquim Nabuco, 1997. Disponível em: $<$ <ile:///C:/Users/user/Downloads/39301-145813-1-PB.pdf> Acessado em 2 de julho de 2019.

HARDMAN, Francisco Foot. Trem Fantasma, a modernidade na selva. São Paulo: Cia das Letras, 1991.

HUGO, Vitor. Os Desbravadores, vol III, Porto Velho: ABG, 1998.

IBGE. Censo demográfico realizado em 1930. A População de Porto Velho. d Disponível em: <https://censo2010.ibge.gov.br/sinopse/index.php?dados=6> Acessado em 14 de abril de 2019.

LABORATÓRIO DE ESTUDOS SOBRE ETNICIDADE, RACISMO E DISCRIMINAÇÃO (USP) - Iconografia. São Paulo: USP. 2019. Disponível em: $<$ http://paineira.usp.br/leer/index.php/linhas-de-pesquisa/iconografia>

LACERDA, Franciane Gama. Migrantes cearenses no Pará. Faces da sobrevivência. (1889-1916). São Paulo, USP, Tese de Doutorado em Ciências, 2006. Disponível em: 
<file:///C:/Users/user/Downloads/TESE FRANCIANE GAMA LACERDA.pdf>

Acessado em 10 de junho de 2019.

LIMA, Frederico Alexandre de Oliveira. Soldados da Borracha: das vivências do passado às lutas contemporâneas. Manaus: UFAM, Dissertação de Mestrado em História, 2013. Disponível em: <https://tede.ufam.edu.br/handle/tede/3723> Acessado em 18 de dezembro de 2017.

LIMA, Abnael Machado de. Porto Velho: de Guapindaia a Roberto Sobrinho (19142009). Porto Velho: IHG/IPARI, Primor, 2012.

MONTENEGRO, Antônio Torres. História Oral e Memória. A cultura popular revisitada. São Paulo: Editora Contexto, 2007.

MORAES, Raymundo. Amphitheatro amazônico. São Paulo. Editora Melhoramentos, 1936.

NASCIMENTO, Maria das Graças. Migrações Nordestinas Para a Amazônia. In: Revista de Educação, Cultura e Meio Ambiente- Dez.-Nº 12, Vol li, 1998. Disponível em:

$<$ http://www.revistapresenca.unir.br/artigos presenca/12mariadasgracasnascimento migracoesnordestinasparaamazonia.pdf> Acessado em 30 de junho de 2019.

NEELEMAN, Gary. Soldados da borracha: o exército esquecido que salvou a segunda guerra mundial. EDIPUCRS,2015.

NETO, Sydenham Lourenço e RAMOS, Vinicius da Silva. História do Tempo Presente, diálogos com a História Pública e como ensino de História: uma experiência exploratória. Aedos, n¹5, v.6, Jul./Dez. 2014. Disponível em: $<$ https://seer.ufrgs.br/aedos/article/viewFile/50931/32258> Acessado em 2 de abril de 2019.

NOGUEIRA, Mara Genecy Centeno. A construção do espaço social em Porto Velho na primeira metade do século XX: Um olhar através da fotografia. Programa de PósGraduação - Mestrado em Geografia da Fundação Universidade Federal de Rondônia (UNIR) 134p. Porto Velho, 2008.

PINHEIRO, Maria Luiza Ugarte. A Cidade Sobre os Ombros: trabalho e conflito no porto de Manaus (1899-1925). 2 ${ }^{\mathrm{a}}$ ed. Manaus: EDUA, 2003.

RIOS, Kênia Sousa. Isolamento e poder. Fortaleza e os campos de concentração na seca de 1932. Fortaleza: Imprensa Universitária, 2014.

SANTOS, Milton. A Natureza do Espaço-Técnica e Tempo, Razão e Emoção. São Paulo: Hucitec, 1997.

SECRETO, Maria Verônica. Soldados da Borracha: Trabalhadores entre o Sertão e a Amazônia no Governo Vargas. São Paulo: Ed. Fundação Perseu Abramo. 2007. 


SIGNIFICADOS. Pesquisa Documental. Disponível em:
$<$ https://www.significados.com.br/pesquisa-documental/>

SILVA, Amizael Gomes da. Da Chibata ao Inferno. Porto Velho: EDUFRO, 2001.

SILVA, José Carlos Meireles. Soldados da borracha. Os heróis esquecidos na Amazônia. In: Revista do Exército Brasileiro. Vol 151. 1ํquadrimestre de 2015. Edição Especial. Disponível em: <https://idd.org.br/wordpress/wpcontent/uploads/2016/04/Soldados-da-borracha-os-her\%C3\%B3is-esquecidos-naAmaz\%C3\%B4nia.pdf> Acessado em 6 de julho de 2019.

SOUZA, Márcio. A Expressão Amazonense: Do colonialismo ao neocolonialismo. São Paulo: Alfa-Omega, 1977. . Breve história da Amazônia. São Paulo, Marco Zero,1994.

SPIVAK, Gayatri Chakravorty. Pode o subalterno falar? Belo Horizonte: UFMG, 2010.

TEIXEIRA, Carlos Corrêa. Servidão humana na terra. O aviamento e o barracão nos seringais da Amazônia. Manaus: Editora valer, 2009.

TEIXEIRA, Marco Antônio Domingues e FONSECA, Dante Ribeiro da. História Regional (Rondônia). Porto Velho: Rondoniana, 1998.

TEIXEIRA, Marco Antônio Domingues. O Rio e os Tempos: Reflexões sobre a colonização e as questões Ambientais no Vale do Madeira Entre os Séculos XVII e XXI. IN: Revista Saber Científico, VOL 1, № 2, Porto Velho, 2008. Disponível em: http://revista.saolucas.edu.br/index.php/resc/article/view/51 Data de acesso: 25/05/2019.

THOMPSON, Paul. A voz do passado: História Oral. São Paulo: Editora Paz e Terra, 1992.

VILELLA, Gustavo. Lei de 1941 considera ociosidade crime e pune 'vadiagem' comprisão de 3 meses. Publicado em 14/12/2014 e atualizado em 30/09/2016. Disponível em: <https://acervo.oglobo.globo.com/em-destaque/lei-de-1941considera-ociosidade-crime-pune-vadiagem-com-prisao-de-3-meses-

14738298\#ixzz5uKzWBOVR>. Acessado em 8 de julho de 2019.

VIEIRA, Noêmia Ramos. O conceito de região e o ensino de geografia: desencontros entre o saber escolar e o saber acadêmico. Revista Formação, n.20, volume 1, Ano 2013 - $\quad$ p. 21-37. Disponível em: $<$ http://revista.fct.unesp.br/index.php/formacao/article/view/2301/2317>. Acessado em 10 de julho de 2019. 